Arabiyat : Jurnal Pendidikan Bahasa Arab dan Kebahasaaraban

\title{
UNVEIL THE MEANING OF IBN AL-FARID'S SUFISTIC POETRY USING THE RIFFATERRE'S SEMIOTICS
}

\author{
Merry Choironi, Ida Nursida \\ Universitas Islam Negeri Sultan Maulana Hasanuddin Banten, Indonesia \\ Jl. Jendral Sudirman No. 30, Panancangan Cipocok Jaya, Kota Serang, Banten, 42118, Indonesia \\ CorrespondingE-mail:merry.choironi@uinbanten.ac.id
}

\begin{abstract}
This study was a multidisciplinary study to interpret symbols behind the words in the Sufism poems of Syaraf al-Din Umar Ibn al-Farid in his diwan, Narm as-Suluk or atTa'iyyah al-Kubra and al-Khamriyyah. Ibn al-Farid resembled his love for his God in beautiful, imaginative, and meaningful poetry. This research used the semiotic literary reading method (al-qirâ'ah al-simi'iyyah) to unveil the meaning of Ibn al-Fārid's Sufistic poetry which is not only about the genre of Sufism un sich, but also the language and literary styles and levels of imagination through heuristic and hermeneutic interpretations. The beauty of his words with its solid essence is very important to be studied, analyzed and conveyed to the public so that the universe of knowledge is exposed not only about the flow of Sufism un sich, but also language and literary styles and levels of imagination through heuristic and hermeneutic interpretations along with the search for matrices, models and variants in the framework of finding the theme, and the final steps is looking for common ground between the texts and the existing ones through the hypogram.
\end{abstract}

Keywords: $\quad$ Semiotics, Sufistics Poetry, Ibn al-Farid

\section{Introduction}

There are at least 3 main elements that complement one's poetry in carrying out its duties to produce a poetry creation, namely empirical exploration or elements of aesthetic experience, elements of beauty, and elements of observation. The poet not only interprets personal concern but also social concern. ${ }^{1}$ In other words, poetry is an attempt by a poet to restore ideas built through text to give meaning to people's lives. The meaning of life is recorded by the poet through his contact with social reality, religiosity, historical context, or personal views. Like historical and social

\footnotetext{
${ }^{1}$ Ahmad Syubbanuddin Alwy, Proses Kreatif dan Konsep Berpuisi, In Mozaik Sastra Indonesia, Dimensi Sastra dari Berbagai Perspektif, edited by Kinayati Djojosuroto and Trully Wungouw, (Bandung: Nuansa, 2005), 77.
} 
Arabiyât Jurnal Pendidikan Bahasa Arab dan Kebahasaaraban, 7 (2), 2020

books, poetry written with experience and thought will mark an inevitable phase in the life of society. Thus, the view of poetry and philosophical thought of poetry has become a paradigm that incised its involvement in the majority of existing ideas as facts. With poetry, someone's expertise as a poet will have a wider meaning in society.

Within the framework of subjective and objective reality with imagination, and its relation to religiosity, naturally, a work of literature, especially poetry as a religious literature works cannot stand by itself. Religious literary works, especially Sufism poetry, are often accused of being away from social reality and also do not care for human health. It is not as subjective reality, nor the objective reality, and not merely the imagination of the poet. For literary works that depart only from subjective reality just pointing to the heavens, a direct relationship with his Lord. While those departing from the objective reality have been more appropriate to say social contextual literature, the inner imagination of the authors who give birth to the masterpiece.

Literary work is a product of a society in the field of culture. Now literature is a cultural witness that continues to be developed. The presence of literature amid technological developments is a big challenge, where literature must be able to inspire real life. It must be able to provide a straight path for humanity. ${ }^{2}$ Besides, literature can also provide a way for humans to obtain the concept of life because literature provides and offers valuable works that contain a lot of truth. When literary works are connected with religion, then literary religious works can be seen as living objects as they are born from a real concept. Moreover, it can be more meaningful because it can solve problems faced in a drab life. Literature not only as a work to be read, but also delivers pleasure and creates a philosophical expression of the mystery of this life. ${ }^{3}$

One of them is Ibn al-Fārid, a Sufi figure of the Fatimid and Ayubid periods in the late $6^{\text {th }}$ and early $7^{\text {th }}$ centuries of Hijri. Ibn al-Fārid packaged his love for his God in beautiful, imaginative, and meaningful poetry. The beauty of his words together with the solid essence is very important to be studied, analyzed, and conveyed to the audience to unveil the universe of knowledge.

\section{Method}

This research used the semiotic literary reading method (al-qirâ'ah alsimia'iyyah) to unveil the meaning of Ibn al-Fārid's Sufistic poetry which is not only about the genre of Sufism un sich, but also the language and literary styles and levels of imagination through heuristic and hermeneutic interpretations. Along with the search for matrices, models, and variants in the context of finding themes, which finally to

2 Syahruddin Y. S. Sastra, Imajinasi, dan Empirisme Relijius, In Mozaik Sastra Indonesia, Dimensi Sastra dari Berbagai Perspektif, edited by Kinayati Djojosuroto and Trully Wungouw, (Bandung: Nuansa, 2005), 80.

${ }^{3}$ Syahruddin Y. S. Sastra, Imajinasi, dan Empirisme Relijius, 50-51; Mahyudin Ritonga, "Puisi Arab Dan Penafsiran Alquran: Studi Tafsir Al-Kasysyaf dan Al-Muharrir Al-Wajiz", Kajian Linguistik dan Sastra, Vol. 27, No. 1, 2015, 1-14. 
Arabiyât Jurnal Pendidikan Bahasa Arab dan Kebahasaaraban, 7 (2), 2020

look for the common ground between the texts and the existing ones through the hypogram. ${ }^{4}$

\section{Result and Discussion}

Riffaterre's Semiotics Theory to Analyze Poetry

Semiotics or semiology is the science of signs. Whether it's in the form of linguistic signs or visual signs. Linguistic signs can be obtained from communication activities, while visual signs are obtained by looking at what is around, such as building shapes, colors, and so on.

However, it should be noted that several disciplines limit themselves to the terms used from the 2 terms that have the Greek root sem-. The first term is semeio and the second term is semant-, sema $(t)$ - where the two terms mean signs, distinguishing features, and predictions. ${ }^{5}$ If semiology is a form of the German word transliterated from the Greek word semeiology, then semiotics (in Greek used for diagnosis), is now used for the designation of particular systems, just as Louis Hjelmslev used the term semiotics for denotative semiotics, connotative semiotics, and Metasemiotics. The second term, semantics, was raised by Breal to become Semantics, the study of the meaning of language. Then appeared semasiology, namely the science of significance, where semasiology departs from words to study meaning, and onosemasiology, the idea of studying expressions

If in linguistics the study of language icons is an entrance into the world of semiotics, 6 then in literature, semiotics is an approach as well as a theory for researching literary works. Furthermore, if semiotic experts consider structure as a sign, while structuralists base their research on the structure of literary works, it is not surprising that structuralists are also called semioticists or vice versa.

Zaimar $^{7}$ mentions there are 5 fundamental theories in semiotic; theory of general principles, triadic, and pragmatic by Charles Sanders Peirce, the theory of synchrony and diachrony, langue and parole, sign language (sing, signifier, signified), and syntagmatic relations and associative or paradigmatics by Ferdinand de Saussure, definition of Semiotics, sign theory and sign classification by Umberto Edo, myth theory by Roland Barthes, and semiotic square theory by Greimas.

Michael Riffaterre, in his book Semiotics of Poetry, states that four things must be considered in understanding and interpreting a poem. They are: (1) poetry is an indirect expression, expressing something with another meaning, (2) heuristic and

4 Rachmat Djoko Pradopo, "Semiotika; Teori, Metode, dan Penerapannya", Humaniora, Vol. 6, No. 7, 1998, 45.

5 Jeanne Martinet, Semiologi Kajian Teori Tanda Saussuran Antara Semiologi Komunikasi dan Semiologi Signifikansi, Translated by Stephanus Aswar Herwinarko, (Yogyakarta: Jalasutra Anggota IKAPI, 2010), 3.

6 Praptomo Baryadi, Teori Ikon Bahasa: Salab Satu Pintu Masuk ke Dunia Semiotika, (Yogyakarta: Universitas Sanata Dharma, 2007).

7 Okee Kusuma Sumantri Zaimar, Semiotika dalam Analisis Karya Sastra, Ke-1. (Depok: PT. Komodo Books Anggota IKAPI, 2014). 
Arabiyât Jurnal Pendidikan Bahasa Arab dan Kebahasaaraban, 7 (2), 2020

hermeneutic (retroactive) reading, (3) matrices, models, and variants, and (4) hypograms. $^{8}$

First, the discontinuity of poetry's expression. This occurs due to a shift in meaning (displacing), distortion of meaning (distorting), and the creation of meaning (creating). Shifts in meaning include the use of figurative language, both metaphor, and metonymy. Damage or deviation of meaning (distorting), occurs because of ambiguity, contradiction, and non-sense. Ambiguity can occur in words, phrases, sentences, or discourses due to the emergence of different interpretations according to the context. Contradictions arise because of the use of irony, paradox, and antithesis. Non-sense are words that have no meaning (according to the dictionary) but have the meaning as "mystical" according to the context. Meanwhile, meaning creation (creating) occurs because of the organization of text spaces, such as enjambment, typography, and homolog.

Second, the readings of Heuristic and Hermeneutic. With the heuristic's way of reading, a poem is read following normative grammars, morphological, syntactic, and semantic to generate overall sense grammatical normative semiotic system first level, then by retroactive or hermeneutics reading, the reader reads the text back and forth to find the meaning of literary works in the highest work system, namely the meaning of the entire literary text as a sign system. ${ }^{9}$

Third, the theory of matrices, models, and variants. The matrix is hypothetical and in the structure of the text, it is only seen as the actualization of words. The matrix may be a word and, in this case, never appears in the text. In analyzing the literature, matrix abstracted in a form of the word, phrase, part of a sentence, or simple sentence. The matrix is a motor or generator of a text. Meanwhile, the model is the actualization of the matrix in a literary work. The matrix is developed by the model, it can be in the form of words that often appear in a literary text. Variants are sentences made as a result of model development. So, we can call the matrix is the theme, the model is the keyword, while the variants are the words developed from these keywords.

Fourth, the hypogram theory. Hypogram is the tracing tradition from previous works. It is done by searching and tracing the background of the literary work's creation. Its background work is called the hypogram itself, while the work produced as a result of the influence of the hypogram is called a transformation. ${ }^{10}$

8 Michael Riffaterre, "Poetic Language", Signo - Theoritical Semiotics on the Web, Applied Semiotics Theories, http://www.signosemio.com/riffaterre/poetic-language.asp accessed June 7, 2020.

9 Michael Rifaterre, Semiotic of Poetry, (Bloomington and London: Indiana University Press, 1978), 2.

10 Qiwarunnisa, Mulyono, and U'um Qomariyah, "Simbolism e Hujan dalam Novel Hujan Karya Tere Liye", Jurnal Sastra Indonesia, Vol. 7, No. 3, 2018, 163. 
Arabiyât Jurnal Pendidikan Bahasa Arab dan Kebahasaaraban, 7 (2), 2020

\section{The Life of Ibn al-Farid}

His full name is Syaraf al-Din Umar ibn Ali ibn Mursyid al-Hamawi alMishri. ${ }^{11}$ His father is a lawyer who always defended the womenfolk in court to get his share (al-furūḍ) over their husband, his father then famously known as Al-Farid. Ibn al-Farid was born in $4^{\text {th }}$ Dzulkaidah $576 \mathrm{H} / 1181 \mathrm{AD}$. He spent most of his life in Egypt and died on Tuesday, $2^{\text {nd }}$ Jumadil Ula 632 AH / 1234 AD.

Many factors that brought up his Sufism, starting from the family's environment in which far from worldly pleasures, filled with servitude to God and very religious, even ascetic. He also has a personality that always tries to protect himself from bad things (wara), has a good temper, also has good words. Besides, his heart is easily touched by beauties, both in real form and only intones. ${ }^{12}$

The social-political circumstances at that time also develop his Sufistic. He grew and lived in an era of two centuries at once, namely the end of the $6^{\text {th }}$ century until the beginning of the $7^{\text {th }}$ century. That period was a period of massive power transition. Egypt and Syria, which were previously under the Fatimid rule, then moved to Ayubid's hands. This means that the religious laws in Egypt and Syria, which previously followed the Shi'a school, have shifted to Ablussunnah. It was also during this period that crusades raged, which caused concern and distress so that Egypt experienced an endless crisis. In the years 598-599 $\mathrm{H}$, the waters of the Nile had receded, causing the agricultural output to decline, epidemics spread, and the security situation was very worrying. Nevertheless, the tradition of knowledge continues to experience significant growth as the rulers of Egypt from Shalahuddin alAyyubi (1174-1193), al-Aziz (1193-1198), al-Mansur (1198-1200), al- 'Ádil I (12001218) and al-Kāmil (1218-1238) are people who love science, literature, and Sufism. Under the rule of al-Ayyubi, al-Azhar revived the Sunni school and banned Shiite teachings because they were considered Fatimid heritage. Schools are built under the flag of Sunni.

Another factor that increasingly grew and developed his Sufism life is the fact that Ibn al-Farid lived in an era with some poet Sufis, such as Safiyuddin bin Abi alMansur and Syamsuddin al-Ayaki, and Hadith scholar Sa'duddin al-Hariś al-Hanbali, also Hakim Aminuddin ibn al-Raqawi, Jamaluddin al-Asyuthi, Syihabudin Ibrahim alSahrawardi, Burhanuddin al-Ja'bari, Ibn Khillikan, Syihabuddin al-Khaimi, and Najmuddin ibn Israil. All of them admitted that they know Ibn al-Farid and his spirituality (ahwal). While direct contact with al-Ja'bari, Ibn al-Khaimi, Umar alSuhrawardi, al-'Asakir, and al-Munźiri were his teacher in the field of Hadith. Including Ibn al- 'Arabi and his Sufism character, wabdat al-wujûd, which was provided the most influence that brought him in the field of Sufism.

11 Ibn al-Farid, Diwân Ibn al-Farid, (t.tp: Dar al-Ma'rifah, 2009), 1; Ibn Khillikan, Wafiyat al-A'yan wa anba abna al-Zaman, (Beirut: Dar al-Tsaqafah, t.t.), 383; Badruddin al-Hasan Ibn Muhammad alBuriyani and al-Syaikh Abdul Ghani Ibn Ismail Al-Nabulusy, Syarh Diwân Ibn Al-Faridh, (Beirut: Dar alKutub al-Ilmiyah, 2003), 4.

12 Ibn al-Faridh, Diwân Ibn al-Farid, 2. 
Arabiyât Jurnal Pendidikan Bahasa Arab dan Kebahasaaraban, 7 (2), 2020

Mustafa Hilmi conclude that there are two different ideas in the era of Ibn alFarid; the first group is very consistent in adhering to religious teachings fundamentally and trying to defend teachings based on the Quran and Hadith, while the second group is the opposite, they free themselves from religious doctrines and even leave the law. Here Hilmi positions Ibn al-Farid in the first group, although it will find a few verses of syatahât poetry ${ }^{13}$ which seem to have left Sharia. Those who belonged to the second is Suhrawardi, who was executed, and Ibn al-'Arabi who was affected by the influence of Neo-Platonism philosophy and teachings of ancient Persian and Shiite doctrine.

\section{Ibn al-Farid and Sufistic poetry}

A collection of Ibn al-Farid's poetry (Diwân) consists of 23 qashîdah, 5 lines of short poetry (muqâthth ‘ât), 31 verses (dubait/ruba ‘iyyah), 19 riddles (alghą), and 1 mawali. This collection of poems was first edited by 'Ali from a manuscript of Ibn alFarid. His longest poem is entitled Nazm al-Suluk which is better known as al-Ta'iyyah al-Kubra.

Therefore, there are two parts of Ibn al-Farid's Sufi-themed poetry, namely the philosophical Sufi poetry and love of Sufi poetry (ghazal). In Sufism philosophical poetry, he brought together many of the terms of Sufism in verses in al-Ta'iyyah alKubra and al-Khamriyyah, while her love poems (ghazal) were manifested in the form of a general description of the various places or areas, various natural phenomena, and various emotions and sensations. ${ }^{14}$ This article, focuses on Ibn al-Farid's poetry within the genre of philosophical Sufism which is compiled in al-Ta'iyyah al-Kubra and alKhamriyyah.

Ibn al-Farid's poetry sentences in al-Ta'iyyah al-Kubra and al-Khamriyyah are considered as a language that transcends denotative forms and direct understanding which creates very wide spaces for interpretation. ${ }^{15}$ Infinite horizons were created through the words which bind Sufistic concepts and perceptions. To provide a proper Indonesian translation, in this case, the author tries to take it from the translation of Uzair Fauzan published by Mizan in a book entitled Tasawnf CintaThe Study of Three Sufis; Ibn Abi al-Khair, al-Jili, Ibn al-Farid (2003).

\section{Heuristic Analysis of Ibn al-Farid Sufistic Poetry}

The following is the verse of Ibn al-Farid's poems from his qashidah al-Ta'izyah al-Kubra:

13 "The Irrational Words that can Lead to Confusion in which often stated by Sufi in their Unconscious state," n.d

14 M. Ilham Shaleh, "Ibn al-Faridj Sya'ir al-Ghazal fi al-Hubb al-Ilahi", Jurnal Adabiyah, Vol. 11, No. 2, 2011, 262.

15 Ibn Muhammad al-Buriyani and Ibn Ismail Al-Nabulusy, Syarh Diwân Ibn al-Farid, 4. 
Ara 6iyât Jurnal Pendidikan Bahasa Arab dan Kebahasaaraban, 7 (2), 2020
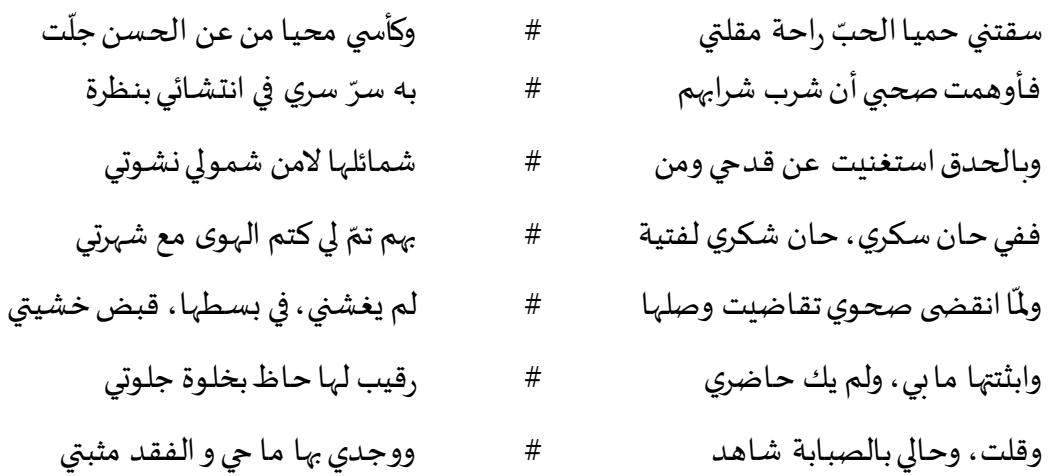

The power of my eyes has given me love like a fine wine to drink when my chalice is His face which transcends beauty

And in my drunkenness, a moment I caused my friends to fantasize that the thing thatpleases soul is to drink their wine

Even though my eyes separate me from my chills, and I get drunk on its quality, not because of my wine

Therefore, the places where I get drunk are the times when I am grateful for the young people who have bidden all my love, even though I was known (as a lover).

And when my 'waking' state has ended, I seek unification with her, and no fear can stand in my courage to seek her.

And when the bride's veil is opened in a private room, when there is no continual pride to accompany me as the overseer, I tell her how I feel.

And I said my state to witness the passionate love and my search for her (in my heart) remove all my mere existence while losing her meant a return to my existence

The heuristic readings from the first to the fourth verses of Ibn al-Fāriđ's God is a poet with his both eyes and watched the beauty and his beautifulness sweetheart in the glass of wine. That is what can make the poet drunk drinking the wine. Not because the wine is stupefied, but the beauty of the Creator that is visible from the glass of wine that creates a sense of favors when drinking the wine. A situation like this can be felt by someone who is in love. Imagining the face of his lover is such a pleasure that it overcomes and eliminates all other pleasures. His actual condition, namely drunkenness from drinking a glass of wine, he considered being in love, passionate longing for his lover, Allah.

From $5^{\text {th }}$ to $7^{\text {th }}$ verses, stated that when he had returned from his state of drunkenness, he tried all to unite with the beloved (God), and with strong courage expresses his feelings of love are passionate. He looked for God in himself until he felt lost because he had merged with God.

\section{Hermeneutic Analysis Ibn al-Farid's Sufiism}

The previous verses show the road in the early stages of his spiritual life (Sufism). At this stage, he still saw his Lord with his senses, through his two 
Arabiyât Jurnal Pendidikan Bahasa Arab dan Kebahasaaraban, 7 (2), 2020

eyes. His love for his Lord was still limited to love for the beauties that brought benefits to him. His love was still biological without understanding the meaning of its existence. He was only motivated to connect with a certain "form," such as a glass of wine. He loved this form as a consequence, not an origin. ${ }^{16}$ The cause of his love was the result of his vision until his imagination of his lover, his God, appears.

The state of sukr (drunkenness) he experienced was also a stage of love for a Sufi. The drunkenness affected his mind and removed it. Mahmūd Gurāb states that suker or al-sakr is the fourth stage of love, after drinking and being full. He added that sukr is a stage of love that eliminates the mind of the lover.

In the verse, one can also find the process of his search for the beloved God. This was of course after he regained consciousness from his drunkenness. He saw everything as a form of his lover until he felt lost merging with his god. Here, we can interpret that his love for God has reached a spiritual process called tajalli syubudi when the potentials that exist in his divine essence take actual form in various natural phenomena. ${ }^{17}$

\section{Matrices, Models, and Variants}

The matrix is a short, elongated sentence. The matrix does not appear in the text, but is present in several models, then actualized into variants.

In this case, the matrix of Ibn al-Farid's love-of-God poems is the stage of love of God. Ibn al-Farid started with a love that was still full of imperfection because they depend on the sensations obtained by the senses. In Sufism, this condition is known as al-fanâ' al-awwal. According to al-Junaidi, ${ }^{18}$ fana $\hat{a}^{\prime}$ is generally defined as the loss of the awareness of heart to the sensory things because of something it sees. Then what he saw was gone and kept changing until his senses were no longer conscious and felt nothing. Al-fanâ' appears in the following verses:

$$
\begin{aligned}
& \text { أراك بك، لي نظرة المتلف }
\end{aligned}
$$

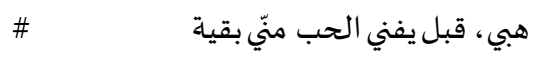

$$
\begin{aligned}
& \text { أراك فمن قبلي لغيري لذت ألذات } \\
& \text { \# }
\end{aligned}
$$

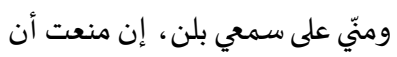

$$
\begin{aligned}
& \text { لها كبدي لولا الهوى لم تفتت } \\
& \text { \# } \\
& \text { فعندي لسكرتي فاقة لإفاقة }
\end{aligned}
$$

Give me the gaze of people who look away for a moment, before love removes what is left in me (selfexistence) to then see you

And if you forbid me to see you, but allow my hearing (to bear You), You must not see me, this sentence sounds sweet to others before me.

Because of drunkenness, I need healing (of the drunkenness) that will not break my beart, except for desire or passion.

16 Mahmud Mahmud al-Gurab, Semesta Cinta Ibnu 'Arabi, Terj. dari Al-Hub Wa al-Mahabbah alIlabiyah Min Kalam al-Syeikh al-Akabr. Translated by Aguk Irawan MN and Kaserun, (Surabaya: Nusantara Press, 2015), 112.

17 Totok Jumantoro and Samsul Munir Amin, Kamus Ilmu Tasamuf, (Medan: Amzah, 2005), 232.

18 Totok Jumantoro and Samsul Munir Amin, Kamus Ilmu Tasanuf, 51. 
Arabiyât Jurnal Pendidikan Bahasa Arab dan Kebahasaaraban, 7 (2), 2020

His love in this first stage has an impact on his love for himself and pleasure or the willingness and compliances of a servant for everything that is given and has been determined by his Lord, as in the following verse of his poem:

$$
\text { ولمع ولمس أحك في حبيك حالي تبرما }
$$

I tell you how much my love for you makes me full, not because impatience has made me weary with my sufferings, but to quell my grief

It is a good thing to show courage to an enemy; but in front of a lover showing everything except weakness, is inappropriate behavior

Whatever suffering I receive is a desire, as long as my aim is firm against denial.

It is very clear that at this stage of Ibn al-Farid's love for god still has a vision of love for himself despite the willingness to endure all the suffering that was inflicted as a result of that love.

The second stage of Ibn al-Farid's love is to eliminate all the living's sensory to the love of oneself through the unification with the beloved (God) which is universal and reach the degree of purity of heart and self. ${ }^{19}$

Ibn al-Farid stated in the verses of the poem below that he has removed the desire of lust as a manifestation of his love:

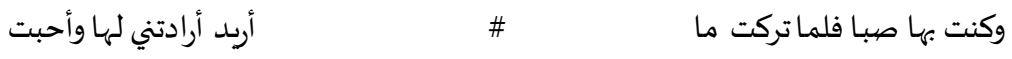

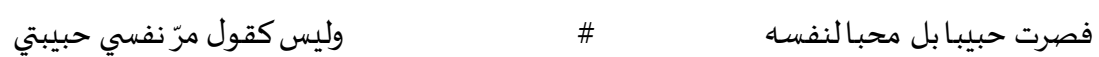

Only when I fell in love with him; but when I put my passion away, she wants me to be herself and to love me

And I became the lover, not someone who loves himself; It is not like I have said before, that my soul is my lover

This second stage of love does not lead to unification with God but to awareness and witness to the existence of the one and only absolute Existence (shuhthd al-maujûd al-wâhidal-mutlaq) and everything that exists comes from Him, does not exist with itself. Besides that, it is impossible if there is one being who can unite with His matter.

As the final stage of Ibn al-Farid's love for his God is the unification of self and this is the culmination of his love and experience in the waking state, not drunk. This state is called a unification which makes sense (ittihâd manthiqi) and is not classified as shath (unconscious state), as stated in verses $214^{\text {th }}-216^{\text {th }}$ below:

19 Muhammad Mustafa Hilmi, Ibnu al-Farid wa al-Hubb al-Ilabi, (Ttp: Matha'ah Lajnah al-Ta'lif w al-Tarjamah wa al-Nasyr, 1945), 138; Muhammad Robith Fuadi, "Memahami Tasawuf Ibnu ARABI dan Ibnu AL Farid", Ulul Albab, Vol. 14, No. 2, 2013. 
Arabiyât Jurnal Pendidikan Bahasa Arab dan Kebahasaaraban, 7 (2), 2020

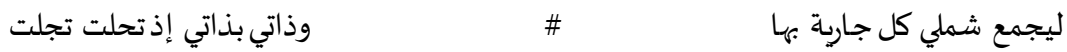

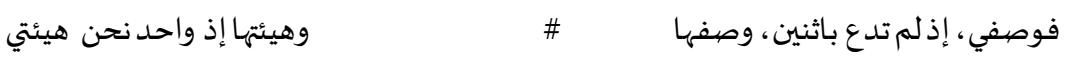

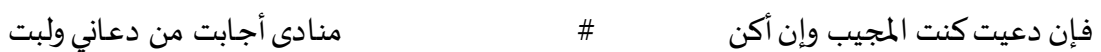

So that in the post-self-winding state, I am none other than her, and when she shows herself, my essence is filled with my essence.

When my essence is considered two, my nature is her nature, and because we are one, the outer aspect is my outer aspect.

If she is called, I will answer, and when I am called, she is the one who answers the person who calls me and shouts "labbaik" (I fulfil your call)

Meanwhile, the model which is the first form of actualization of the matrix found in Ibn al-Fāridh's poetry of love is the word love (bubb), drunkenness (sakr), testimony (syubud). The following will describe the form of the model one by one.

The word hubb(love) and its derivation is the most form of matrix actualization in Ibn al-Fāridh's poetry. He often used the word bubb in the form of verbs, nouns, actor nouns, object nouns, and adjectives. The repetition of the word $h u b b$ which is too often shows that the stages of his love which become a matrix are actualized in the form of clear words, namely bubb and also their derivations. According to Riffaterre's semiotic theory, the word $b u b b$ has become a model that will develop a matrix, so that the stages of love can be expressed through the word $h u b b$ and its various derivations.

In the verb form, the word bubb is used as in the following verses:

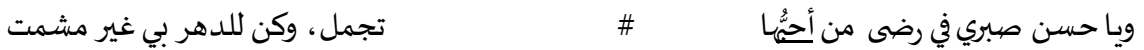

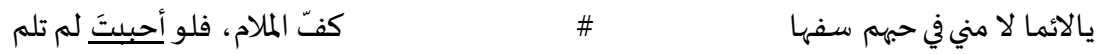

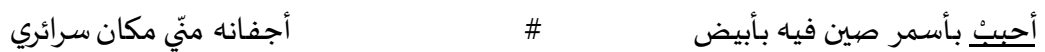

In the noun form, the word hubb is singular like the following:

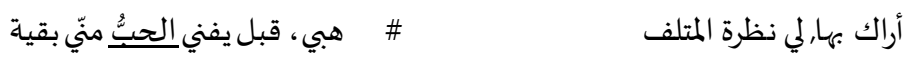

and there are those which are compound words, namely jawa albubb (passionate love), such as:

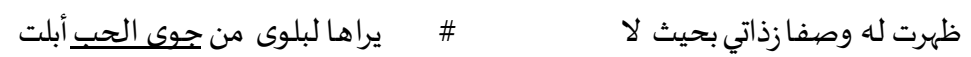

and taubid al-hibb / al-bubb (union of love), such as:

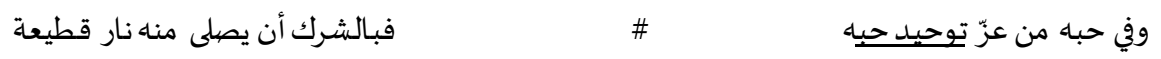

The second model is found in the love poems of Ibn al-Farid is sukr (drunk). Sukr is the feeling of the abundance of Allah's love in the heart and unification of oneself with his Lord after eliminating all sensory senses. This ecstatic condition is a stepping stone to sahw (conscious and awake) so that it becomes a model for describing the process of fusing with his God in a conscious state, no 
Arabiyât Jurnal Pendidikan Bahasa Arab dan Kebahasaaraban, 7 (2), 2020

longer in ecstasy or drunkenness. At least Ibn al-Farid stated sukr or ecstasy condition as much as 9 times and everything is in the form of the noun, either single or part of a compound word, as in the following:

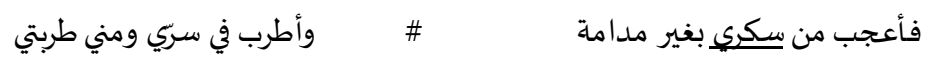

Syuhûd (testimony) is the third model who became one of the actualizations of the love-of-God poems matrix of Ibn al-Farid. In Sufism, shuhûd is a testimony to God in all of His Self-revealing. Word syubûd was found 21 times in the ta-iyyah kubra of Ibn al-Farid. Following an expression of Ibn al-Farid in the poem by using word syuhûd:

$$
\text { وشاهدت نفسي بالصفات التي بها ت تحجيت عني في شهودي وحجبتي }
$$

or its derivation as in the following verses:

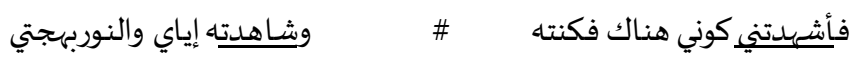

Through the word syubûd, Ibn al-Fārid spread his thoughts about the flow of Sufism attributed to him, namely al-wahdah al-syubûd. Some argue that the concept of Ibn al-Fāridh's al-wahdah syuhûd is similar to Ibn 'Arabī's al-wabdah al-wujûd.

Riffaterre invites literary researchers to then look for variants of the above model. Let us look again at the models that have been found, then determine the variants;

The model in the form of the word $h u b b$, has been in various forms of the word transformation, such as al-'Isyq, al-Hawa, al-Java, and al-Gharam. These words are contained in Ibn al-Farid's love poem:

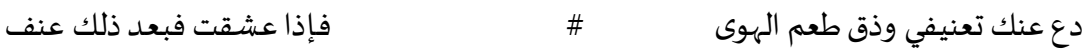

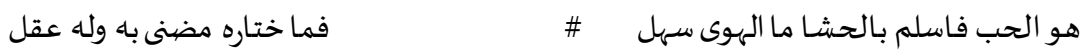

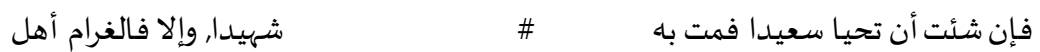

In the first verse seems Ibn al-Farid unify the meaning of al-'ishq, al-Hawa, AlJava, and al-Gharam with hubb, whereas other scholar of Sufism distinguishes them.

Also, sometimes Ibn al-Farid describes the condition of the body and soul filled with love using the term philosophy, as mustabil and wajib, as in verses:

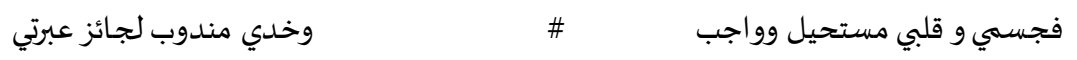

Ibn al-Farid also borrow nabwu (Arabic syntax) terms to convey the intent of his heart, as in the following:

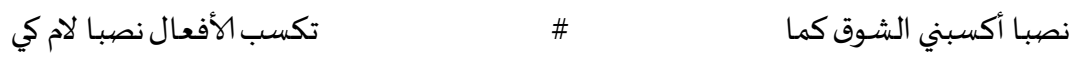

The model in the form of the word sukr has variants such as khamr (wine), mudâmah (wine) and nishwah (ectasy). At the earliest level, khamar or mudamah symbolizes his love for his Lord which causes sukr (drunkenness) and nishwah (ectasy). The following poem of Ibn al-Farid are using variants of the model of sukr: 
Arabiyât Jurnal Pendidikan Bahasa Arab dan Kebahasaaraban, 7 (2), 2020

$$
\text { ومازلت في نفسي بها مترددا }
$$

While the symbol of mudamah appears as follow:

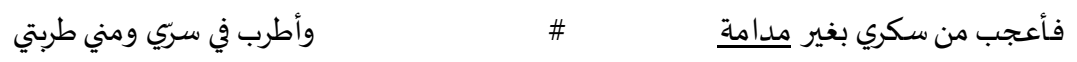

Wahid Behmardi said ${ }^{20}$ in his thesis on the relationship between sukr with symbol khamris that the khamr is the principal branches of esoteric knowledge (Irfâni) Ibn al-Farid, though khamr is not the only means for him toward sukr and the ecstasy of the soul. The highest facility is to witness the attraction of love in the universal maqâm unit (wihdah kulliyah).

As a variant of the third model, syuhûd, among others: ârâ (see), and tajalli (unveiling). Ibn al-Farid expressed in the following verses:

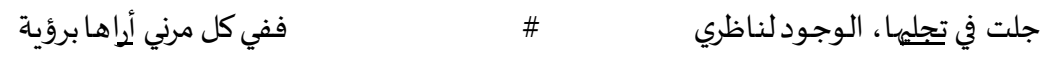

In the following verses, Ibn al-Farid using symbol ara as a form of testimony:

$$
\text { وأسـألني رفعي الحجاب بكشفي ال }
$$

\section{Hypogram in Ibn al-Farid's Sufism Poetry}

Hypograms are not only a way to connect the work that was born with the previous works that influenced it, but according to Riffaterre, the hypogram is a precursor that is considered the poetic energy of the text. Here, Riffaterre places the hypogram as inspiration for the next text and to produce meaning in a poem through the words in the work that inspire it. ${ }^{21}$ The hypogram of Ibn al-Fāriḍ's poem of love for God are, among others:

1. Al-Qur'an al-Karim

- Surah at-Taubah (9) verse 128

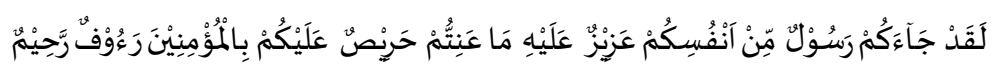

128. There certainly has come to you a messenger from among yourselves. He is concerned by your suffering, anxious for your well-being, and gracious and merciful to the believers.

The verse form of transformation contained in Ibn al-Farid's poetry of love of God, in the following:

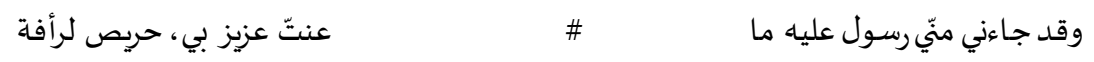

When from myself and for me a prophet appears, who considers my sinful deeds to be sorrowful, someone keeps me from feeling pity.

20 Wahid Behmardi, Al-Lughah al-Sufiyah wa Musthalahuba fi Syi'r Ibnu al-Farid, (Beirut: Jamiah Amrikiyah fi Beirut, 1986), 78.

${ }^{21}$ Merry Choironi, Al-Naqd al-Adabi al-Arabi, (Serang: Lembaga Penelitian IAIN Sultan Maulana Hasanuddin, 2013), 130. 
Arabiyât Jurnal Pendidikan Bahasa Arab dan Kebahasaaraban, 7 (2), 2020

Hypogram here belongs to the actual hypogram, as Ibn al-Farid actualizing the Qur'anic verses that form the text into the text of the poem above. If the article above explains about the birth of the Prophet who was figured same as other human beings, who felt what was suffered by his people, who had a vision of a savior for the believers by their very nature were forbearing and merciful, the Ibn al-Farid created text transformation in the form of the poetic verses by modifying and manipulating the linguistic level of the above verse, such as the object "you" in the verse is replaced by "I". Thus, it can be understood that Ibn al-Farid in the process of his love with his God felt a very heavy burden like that of a prophet. He felt a big responsibility for himself to always be safe and secure. This self (prophet) was also the one who felt affection from himself and for himself too. This shows that his existence as a messenger of his God for himself and he felt that his love for his God was a very heavy burden so he hoped that his God's love would cover him, as he reiterated in the next verse:

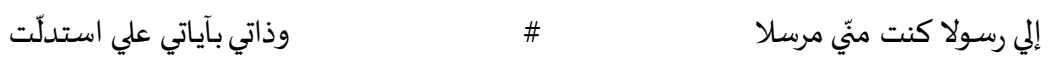

I am an apostle sent to myself, and my essence is directed toward me by the evidence of my own signs.

- Surah at-Taubah (9) verse 111

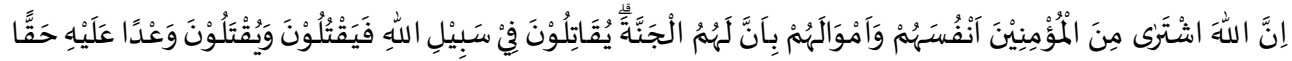

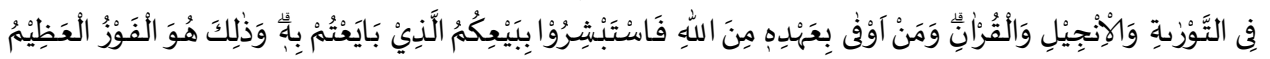

111. Allah has indeedpurchased from the believers their lives and wealth in exchange for Paradise. They fight in the cause of Allah and kill or are killed. This is a true promise binding on Him in the Torah, the Gospel, and the Quran. And whose promise is truer than Allab's? So rejoice in the exchange you have made with Him. That is 'truly' the ultimate triumph.

The above verse is transformed by Ibn al-Farid into the following poetry is:

$$
\text { وقلمّا نقلت النفس من ملك أرضها }
$$

And when I deliver my soul, through an exchange, from its realm to the kingdom of heaven

Because he had struggled and died as a martyr to fight for his cause and had abandoned the enjoyment of his contract when he paid the consequences.

It looks like Ibn al-Farid tapped into the essence of the verse above into the text of the poem (ekeserp). He had made buying and selling transactions with his God until he died as a martyr (syahid) to reach heaven. Said Jannab and bai'un on a paragraph of text transformation hypogram contained in the temple of love poems of Ibn alFarid. By knowing this hypogram, the poemcan be interpreted that Ibn alFarid expressed his love by sacrificing his wealth and even his life for the sake of God's heaven. He carried out a buying and selling transaction with his God, he also believed with all his heart that his God would not deny his payment, even he no longer thought about the amount of payment to be given, except only wanted to go to the heavenly palace that he loved. This hypogram is included in the potential because 
Arabiyât Jurnal Pendidikan Bahasa Arab dan Kebahasaaraban, 7 (2), 2020

it takes the idea from the hypogram. This hypogram is also included in the actual type of hypogram because it also actualizes the text of the verses of the Quran into the poetry text through the two words mentioned earlier, jannah and bai'un.

\section{Hadith}

With further investigation, it will be found out in some of his verses, Ibn alFarid's transformation towards hypogram in the form of hadith of the Prophet narrated by Abdullah ibn Mas'ud in Jâmi' al-Saghîr by al-Suyuti following this: حفّت الجنة " بالمكاره وحفت النار بالشهوات which means: "The (Hell) Fire is surrounded with all kinds of desires and passions, while Jannab (heaven) is surrounded with adversities."

The form of the transformation is in the following verse:

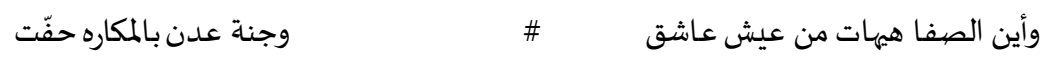

Serenity! How far away it is from the life of the lover! A paradise garden surrounded by terror

The relationship between the two texts is clear. Ibn al-Farid made a transformation from its original text (hypogram), both meaning and pronunciation so the hypogram is classified as actual and potential. Themes raised by the Hadith about the state of heaven and hell together with the theme of the text transformation, only Ibn al-Farid did not mention the condition of hell. Ibn al-Fāridh modified his poetry text by manipulating word sequences such as the word حفت it is placed at the end of the verse, although it does not reverse the matrix.

\section{Conclusion}

Ibn al-Farid's poetry sentences in al-Ta'iyyah al-Kubra and al-Khamriyyah are considered as a language that transcends denotative forms and direct understanding which creates vast spaces for interpretation. He created infinite horizons through the words which bind Sufistic concepts and perceptions. Through the heuristic analysis of Riffaterre's semiotic theory, it is revealed that the poet of Ibn al-Farid, saw his lover in his wine chalice. The taste of love was so deep made it so heavenly when drinking it. His drunkenness was caused by love. After he regained consciousness, he continued to look for the form of his lover until he reached the end when he felt himself melting with her lover.

Hermeneutic studies have been able to interpret the 7 initial verses of alTa'iyyah al-Kubra of Ibn al-Farid as the early stages of his spiritual life (sulukk). The lover is interpreted as a God whom he saw that made him drown in love is a biological love that is still related to "form", not the origin. Drunk (sukr) also occupies the position of one of the stages of his love for God in the future. Then he continued the next stage after awakening from sukr and finally attained a spiritual process called tajalli syubudi.

Likewise, Riffaterre's Matrix Theory, Model, and Variant manage to find the key sentence: the stages of love as the generator of a series of Ibn al-Fāriḍ's poetry texts in alTa'iyyah al-Kubra. Then the Model theory can collect several words that are often used in texts, namely love (bubb), drunkenness (sakr), testimony (syubudd) as the actualization 
Arabiyât Jurnal Pendidikan Bahasa Arab dan Kebahasaaraban, 7 (2), 2020

form of the matrix. Through variant theory, bubb is manifested in other words al-'Isyq, al-Hawa, al-Jawä, and al-Garām which he sometimes used in one meaning, namely bubb or love, although sometimes he distinguished between them. Sukr is found in another form, namely khamr (wine), mudâmah (wine), and nishwah (ecstasy). Meanwhile, testimony is occupied by other words such as ârâ (seeing) and tajalli (revelation). Hypogram is a way to find the relationship between the Sufistic poetry text of Ibn alFarid with the Quran and Hadith. As Ibn al-Farid actualizes the verses of the Quran in the form of the text into the text of his poems, then his hypogram is classified as the actual hypogram. Elsewhere Ibn al-Farid transformed its original text form of the hadiths' meanings and pronunciations that made his hypogram to be classified into actual and potential. []

\section{REFERENCES}

Alwy, Ahmad Syubbanuddin. Proses Kreatif dan Konsep Berpuisi, In Mozaik Sastra Indonesia, Dimensi Sastra dari Berbagai Perspektif, edited by Kinayati Djojosuroto and Trully Wungouw. Bandung: Nuansa, 2005.

Baryadi, I. Praptomo. Teori Ikon Bahasa: Salah Satu Pintu Masuk ke Dunia Semiotika. Yogyakarta: Universitas Sanata Dharma, 2007.

Behmardi, Wahid. Al-Lughah al-Sufiyah wa Musthalahuha fi Syi'r Ibnu al-Farid. Beirut: Jamiah Amrikiyah fi Bairut, 1986.

al-Buriyani, Badruddin al-Hasan Ibn Muhammad., and al-Syaikh Abdul Ghani Ibn Ismail Al-Nabulusy, Syarh Diwân Ibn al-Farid, (Beirut: Dâr al-Kutub al-Ilmiyah, 2003), 4.

Choironi, Merry. Al-Naqd al-Adabi al-Arabi. Serang: Lembaga Penelitian IAIN Sultan Maulana Hasanuddin, 2013.

Fuadi, Muhammad Robith. "Memahami Tasawuf Ibnu Arabi dan Ibnu al-Farid", Ulul Albab, Vol. 14, No. 2, 2013.

al-Gurab, Mahmud Mahmud. Semesta Cinta Ibnu 'Arabi. Terj. dari Al-Hub Wa alMahabbah al-Ilabiyah Min Kalam al-Syeikh al-Akabr, Translated by Aguk Irawan MN and Kaserun. Surabaya: Nusantara Press, 2015.

Hilmi, Muhammad Mustafa. Ibnu al-Farid wa al-Hubb al-Ilabi. Ttp: Mathba'ah Lajnah alTa'lif wa al-Tarjamah wa al-Nasyr, 1945.

Ibn al-Faridh. Diwân Ibn al-Farid. t.tp: Dâr al-Ma'rifah, 2009.

Ibn Khillikan. Wafiyât al-A'yan wa anba abna al-Zamân. Beirut: Dar al-Tsaqafah, t.t.

Jumantoro, Totok., and Samsul Munir Amin. Kamus Ilmu Tasawuf. Medan: Amzah, 2005.

Martinet, Jeanne. Semiologi Kajian Teori Tanda Saussuran Antara Semiologi Komunikasi dan Semiologi Signifikansi, Translated by Stephanus Aswar Herwinarko. Yogyakarta: Jalasutra Anggota IKAPI, 2010.

Pradopo, Rachmat Djoko. "Semiotika; Teori, Metode, dan Penerapannya", Humaniora, Vol. 6, No. 7, 1998. 
Arabiyât Jurnal Pendidikan Bahasa Arab dan Kebahasaaraban, 7 (2), 2020

Qiwarunnisa, Mulyono., and U'um Qomariyah. "Simbolisme Hujan dalam Novel Hujan Karya Tere Liye”, Jurnal Sastra Indonesia, Vol. 7, No. 3, 2018, 163.

Riffaterre, Michael. Semiotic of Poetry. Bloomington and London: Indiana University Press, 1978.

Riffaterre, Michael. "Poetic Language", Signo - Theoritical Semiotics on the Web, http://www.signosemio.com/riffaterre/poetic-language.asp accessed June 7, 2020 .

Ritonga, Mahyudin. "Puisi Arab dan Penafsiran Alquran: Studi Tafsir Al-Kasysyaf dan Al-Muharrir Al-Wajiz", Kajian Linguistik dan Sastra, Vol. 27, No. 1, 2015.

Shaleh, M. Ilham. "Ibn al-Farid Sya'ir al-Ghazal fi al-Hub al-Ilahi", Jurnal Adabiyah, Vol. 11, No. 2, 2011.

Y.S., Syahruddin. Sastra, Imajinasi, dan Empirisme Relijius, In Mozaike Sastra Indonesia, Dimensi Sastra dari Berbagai Perspektif, edited by Kinayati Djojosuroto and Trully Wungouw. Bandung: Nuansa, 2005.

Zaimar, Okee Kusuma Sumantri. Semiotika dalam Analisis Karya Sastra, Ke-1. Depok: PT. Komodo Books Anggota IKAPI, 2014. 